\title{
Debtor Data Collection Information System at PT. PNM Pematangsiantar Branch
}

\author{
Erwin Sirait ${ }^{1 *}$, Sahat Sonang ${ }^{2}$ \\ ${ }^{1,2}$ Teknik Komputer, Politeknik Bisnis Indonesia, Indonesia \\ E-mail: esirait946@gmail.com, sahatsonangstg@gmail.com
}

\begin{abstract}
This study aims to create a web-based debtor information system at PT. PNM Pematangsiantar Branch. The design and manufacture are intended to facilitate debtor data management. So that employees can easily enter debtor data without having to write it conventionally. Using conventional methods has a negative impact. One of the negative effects of the system that is still in use is data search, data retrieval will take time because you have to open documents one by one. In addition to data search, data collection on prospective debtors wishing to establish a working relationship with companies is also a negative impact from conventional methods. With this application, it is hoped that the processing and data collection of debtor data will be faster and more accurate. The information system to be designed will be in the form of a web and use a MySQL database. It is hoped that this research can solve the problem of debtor information systems at PT.PNM Pematangsiantar Branch.
\end{abstract}

Keywords: Branch; Conventionally; Systems, Information; Debtor

\section{Introduction}

Information technology is currently increasingly advanced and also as a form of process for advancement in the field of information and communication. Information technology is not only limited to computer technology, but also includes telecommunications technology. In other words, information technology is the result of a combination of computer technology and telecommunications technology. Technology is a scientific method to achieve practical goals, applied science (KBBI).

Information is the result of processing, manipulation and organization of a group of data that has knowledge value for its users. Information technology is simply the term various things and capabilities used in the formation, storage and dissemination of information.

The broader definition of information technology is a technology used to process data, including processing, obtaining, compiling, storing, manipulating data in various ways to produce quality information, namely information that is relevant, accurate and timely, which is used for personal purposes., business, and government and is strategic information for decision making.

The public may often hear the term Debtor Information System. However, not necessarily many people understand about the Debtor Information System and its purpose. In general, SID is stimulated in Bank Indonesia Regulation Number 9/14 / PBI / 2007 dated November 30, 2007. The Debtor Information System contains data on bank debtors who are customers at private banks and state-owned banks.

Debtor Information System is a system that exchanges debtor data information with credit facilities from Banks and Financing Institutions, and is managed by the Credit Information Bureau (BIK). In this case, the two institutions are free to exchange information if they want to find out debtor data and this is legal. Credit Information Bureau (BIK) is a division of Bank Indonesia.

Using conventional methods has a negative impact. One of the negative impacts of the system that is still in use is data search, data retrieval will take time because you have to open documents one by one. In addition to data search, data collection on prospective debtors who wish to have a working relationship with companies is also a negative impact from conventional methods.

By knowing the negative impact, company members need a system that can properly collect data. Improvements were made by creating a computerized debtor data collection system in terms of debtor data collection, loan data, debtor data generation processes, and other processes related to debtors and the company.

\section{Literature Review}

Along with the times and the increasing power of human creativity, there are many developments in science and technology which are quite rapid. One of the developments is in the field of information technology. The need for information that is used as the basis for decision making in every organization is increasingly needed. Therefore more and more job automation today involves the use of computer technology and information systems [1]-[10]. The use 
of technology in its development plays a very important role in life. By utilizing advances in information technology, we can simplify work so that all problems concerning the provision of information can be resolved effectively and efficiently [11s], [12]. Information system design is currently also widely applied to support the activities of a company, including: designing a website as a media for promotion and product sales [13], [14], [15], Designing Information Systems for inventory data collection and logistics of fixed assets [16], [17], [18], sales information system design [19], and implementation of other information system design [20], [21]-[23].

\section{Method}

\subsection{System Design Methods}

The system design is carried out in stages, namely: making a context diagram and continuing with making the ERD database to be designed. After that, the required forms and reports are designed. After the design phase is complete, then proceed with the system implementation stage using PHP and MySQL DBMS

\subsection{Context Diagram}

Context diagram in designing an information system which is a tool in designing in general the design that will be made aims to determine the state of the system to be built. We can see the context diagram in Figure 1 below:

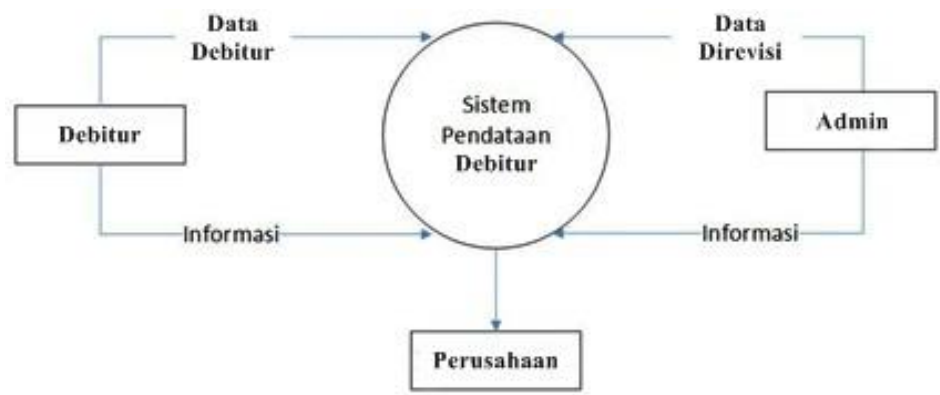

Figure 1 Context Diagram

\subsection{Process Design}

The design of DFD (Data Flow Diagram) is a diagram that uses notations to describe the flow of system data, whose users are very helpful for understanding the system in a logically structured and clear manner. DFD is a tool to describe or explain the system that is running.

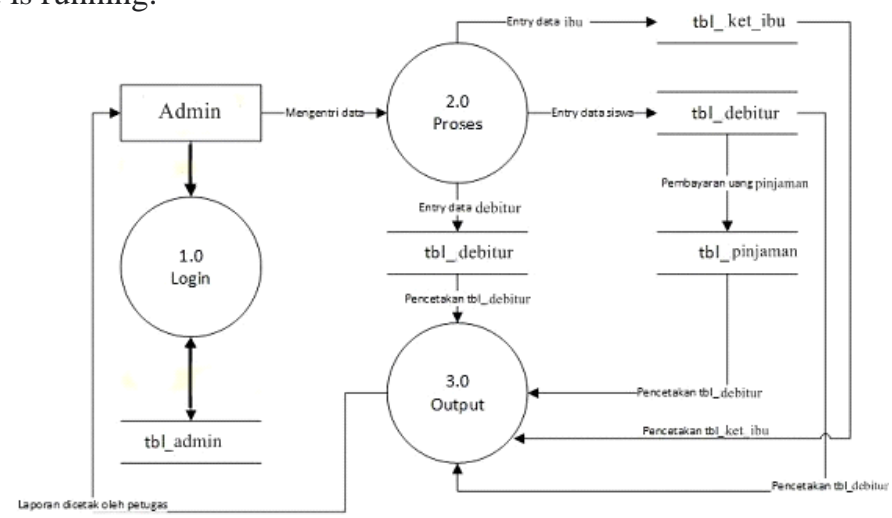

Figure 2 Data Flow Diagram

\subsection{Design Input}

The input design is a design required by a system designed to enter data. The following is an overview of the draft input for the Debtor Data Collection Information System at PT. PNM Pematangsiantar Branch. 


\section{PT. PNM CABANG PEMATANGSIANTAR}

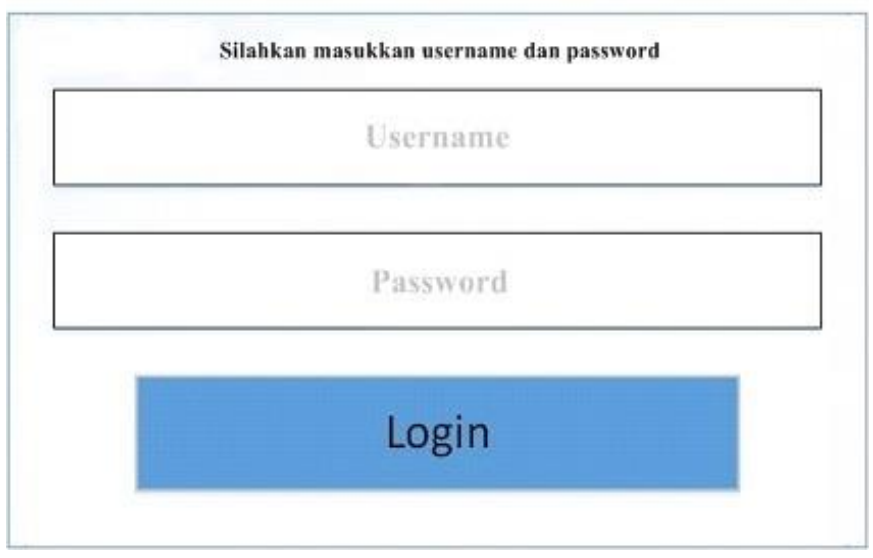

Figure 3 Login Form

\subsection{Debtor Data Input Form}

The result of the Debtor Data page design can be seen in Figure 4

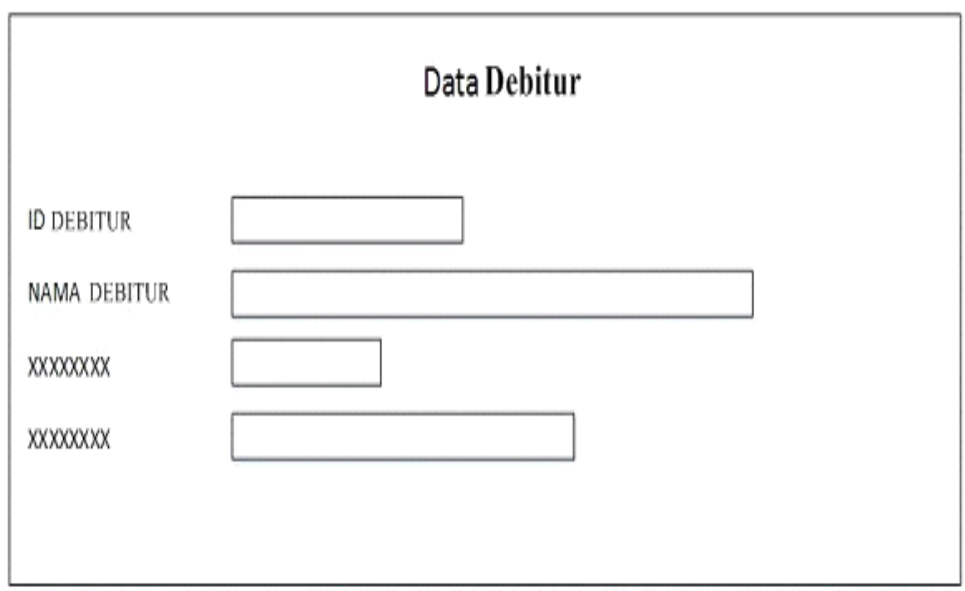

Figure 4 Debtor Data Input

\subsection{Loan Data Input Form}

The result of the Loan Data Input page design can be seen in Figure 5 


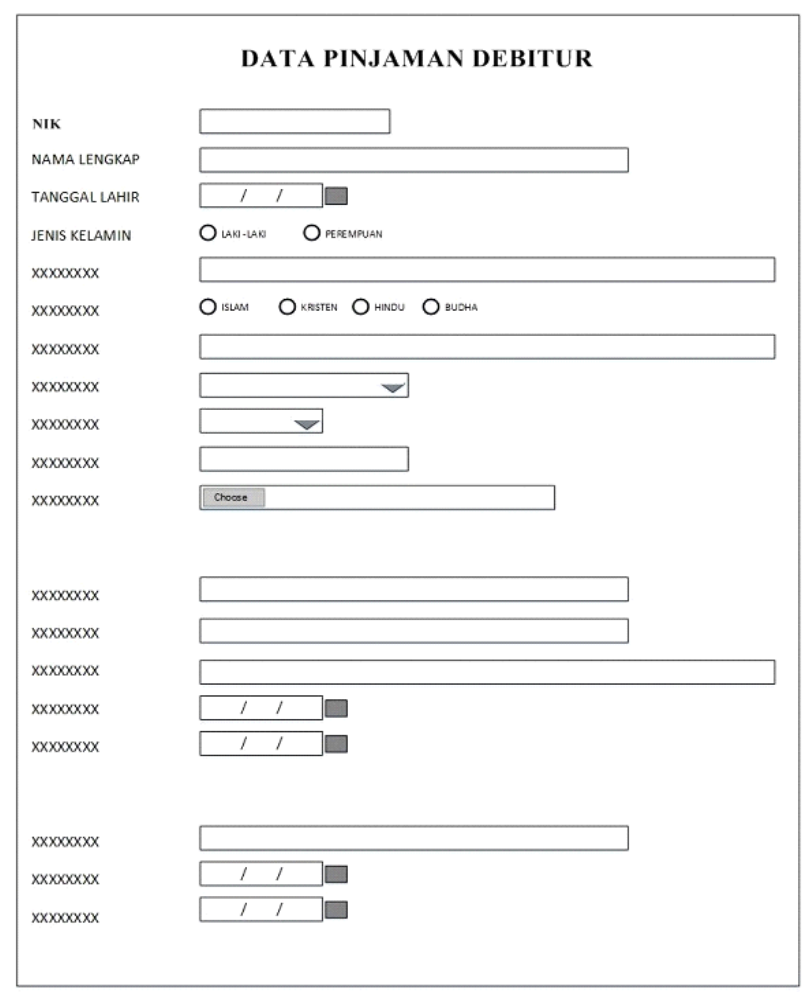

\section{Result}

Figure 5 Loan Data Input

The results of the implementation of the Debtor Data Collection information system at PT. PNM Pematangsiantar Branch. consists of :

\subsection{Debtor data page}

The debtor data page contains data, starting from name, birth date / birth address, gender, and viewing details of debtor data. Staff can add, change and delete member data on this page. Debtor data page implementation can be seen in Figure 6

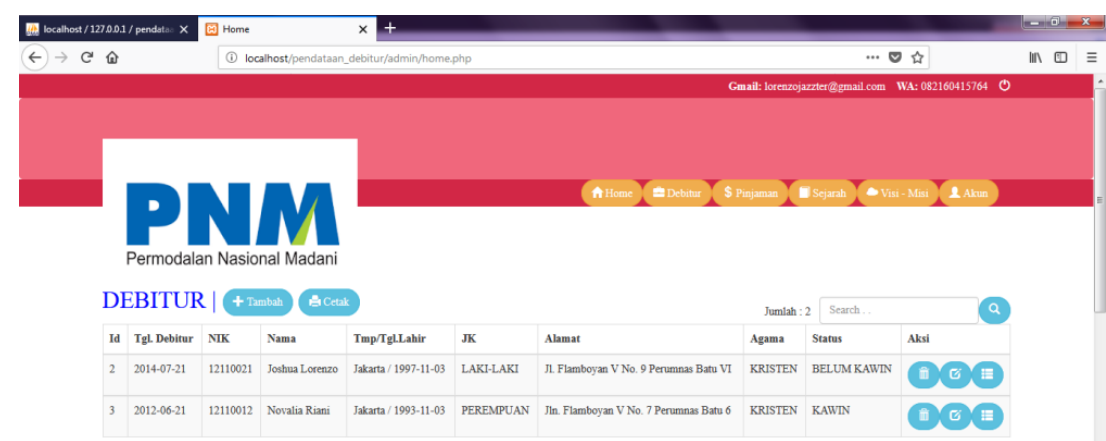

\subsection{Loan Data page}

Figure 6 Debtor Page Implementation

The loan application page displays data on loan applications that have been submitted by members. The following is the implementation of the Loan Request page, it can be seen in Figure 7 


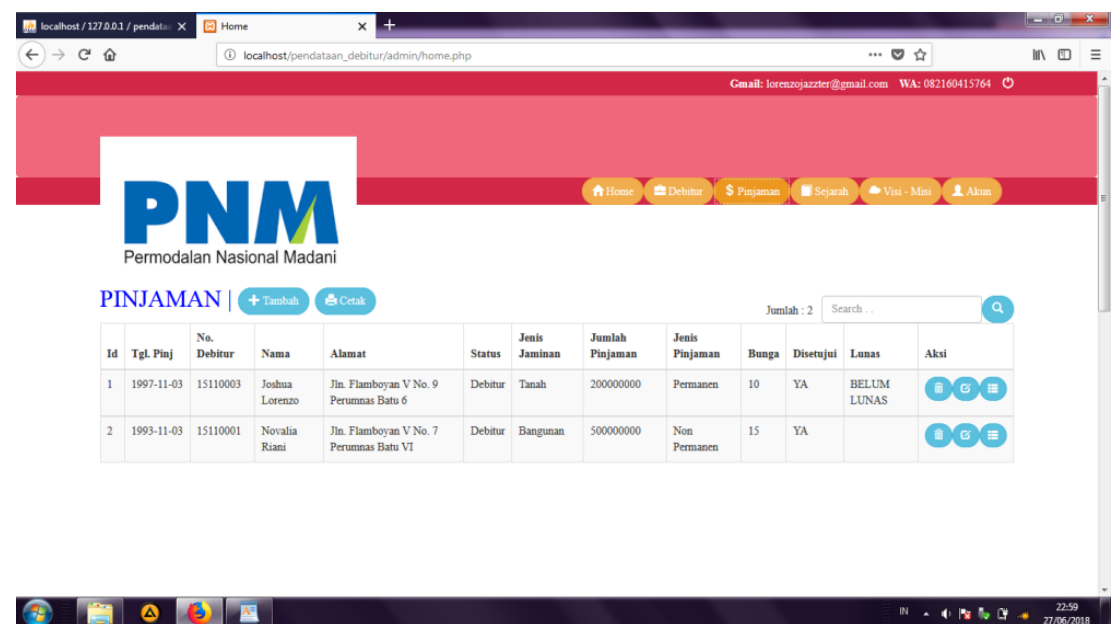

Figure 7 Loan Data Page Implementation

\subsection{Loan Data Print Page}

Page Print Loan Data, which is a menu that functions to print and ensure the correctness and accuracy in checking debtor loan data that has been inputted into the existing system within the company. We can see the image of the Print Loan Data page in Figure 8.

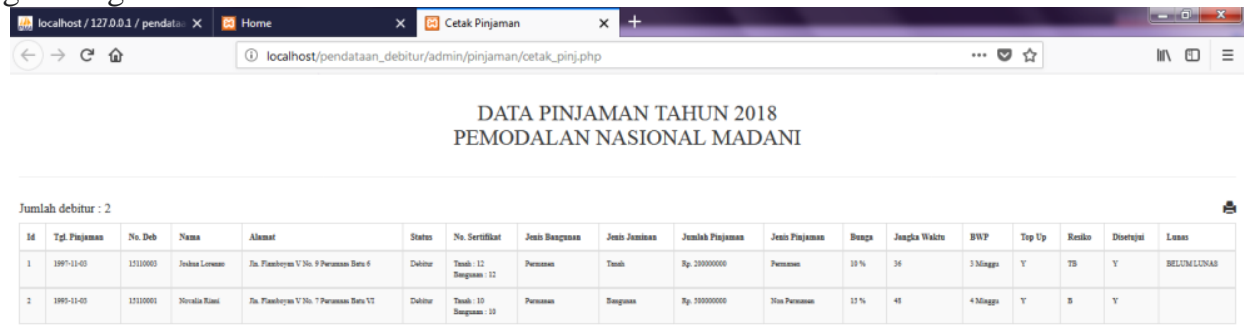

Figure 8 Loan Data Print Page

\section{Conclusion}

From the results of the implementation of the Debtor Data Collection Information System at PT. PNM Pematangsiantar Branch which was built, can be concluded as follows:

1. Debtor Data Collection Information System can help facilitate the PT. PNM Pematangsiantar Branch in processing and archiving debtor data

2. With the Debtor Data Collection Information System at PT. PNM Pematangsiantar Branch staff work in processing loan data and preparing reports can be done more efficiently and effectively

\section{REFERENCES}

[1] J. Simatupang and S. Sianturi, "PERANCANGAN SISTEM INFORMASI PEMESANAN TIKET BUS PADA PO. HANDOYO BERBASIS ONLINE," J. Intra Tech, vol. 3, no. 2, pp. 11-25, 2019.

[2] V. Sihombing and G. J. Yanris, "PENERAPAN APLIKASI DALAM MENGOLAH ASET DESA (STUDI 331 
KASUS: KEPENGHULUAN SRI KAYANGAN),”J. Mantik Penusa, vol. 4, no. 1, pp. 12-15, 2020.

[3] V. Sihombing, "Aplikasi Simade (Sistem Informasi Manajemen Desa) Dalam Meningkatkan Pelayanan Administrasi di Kepenghuluan Bakti Makmur Kecamatan Bagan Sinembah Kab. Rokan Hilir Riau," SISTEMASI, vol. 7, no. September, pp. 292-297, 2018.

[4] J. Simatupang, "Perancangan Sistem Inventori Barang pada Toko Nichos Jaya Menggunakan Metode FIFO," J. Intra Tech, vol. 1, no. 1, pp. 31-42, 2017.

[5] V. Sihombing, "Sistem Informasi Penjualan Mobil Suzuki Di Dealer Bagan Batu," SISTEMASI, vol. 7, no. 2, pp. 113-119, 2018.

[6] W. Purba, S. Aisyah, and S. P. Tamba, "Perancangan Sistem Pakar Diagnosa Penyakit Mata Katarak Menggunakan Konsep Metode Runut Mundur," JUSIKOM PRIMA (Junal Sist. Inf. Ilmu Komput. Prima), vol. 1 , no. $1,2017$.

[7] G. J. Yanris, "Analisis Dan Implementasi Data Mining Dalam Menganalisa Kendala Akademik Yang Sering Dikeluhkan Mahasiswa AMIK Labuhanbatu (Studi Kasus $\square$ : Amik Labuhanbatu)," Informatika, vol. 4, no. 1, pp. 15-24, 2016.

[8] Fricles Ariwisanto Sianturi, "Analisa metode teorema bayes dalam mendiagnosa keguguran pada ibu hamil berdasarkan jenis makanan," Tek. Inf. dan Komput., vol. 2, no. 1, pp. 87-92, 2019.

[9] A. Ardian, I. Purnama, and V. Sihombing, "Perancangan Aplikasi Pengolah Data Siswa Berbasis Android (Studi Kasus $\square$ : Mis Nurul Huda Labuhan Batu Selatan)," Pengabdi. Masy. Ika Bina En Pabolo, vol. 1, no. 1, pp. 40-53, 2019.

[10] W. Purba, S. Tamba, and J. Saragih, "The effect of mining data k-means clustering toward students profile model drop out potential," J. Phys. Conf. Ser., vol. 1007, no. 1, p. 12049, 2018.

[11] A. T. Purba and V. M. M. Siregar, "Sistem Penyeleksi Mahasiswa Baru Berbasis Web Menggunakan Metode Weighted Product," TEKINKOM, vol. 3, no. 1, pp. 1-8, 2020.

[12] S. S. S, A. T. Purba, and V. M. M. Siregar, "Sistem Pendukung Keputusan Kelayakan Pemberian Pinjaman Kredit Menggunakan Metode Topsis Pada Cum Caritas HHKBP Pematangsiantar," J. Tek. Inf. dan Komput., vol. 3, no. 1, p. 1, Sep. 2020.

[13] A. Tina, "Perancangan Website Sebagai Media Promosi Dan Penjualan Pada CV Simba Jaya Magelang," Indones. J. Netw. Secur., vol. 6, no. 1, pp. 9-13, 2017.

[14] H. A. Simbolon and V. M. M. Siregar, "Perancangan Sistem Informasi Berbasis E-Commerce Untuk Peningkatan Penjualan Produk Jersey Olah Raga," J. Tek. Inf. dan Komput., vol. 1, no. 2, pp. 49-54, 2018.

[15] V. M. M. Siregar, "Perancangan Website Sebagai Media Promosi Dan Penjualan Produk," TAM (Technology Accept. Model., vol. 9, no. 1, pp. 15-21, 2018.

[16] V. M. M. Siregar, "Perancangan Sistem Informasi Inventaris Barang Pada Sekolah SMA Negeri 4 Pematangsiantar," IT J. Res. Dev., vol. 3, no. 1, pp. 54-61, 2018.

[17] V. M. M. Siregar, "Sistem Informasi Pendataan Logistik Aktiva Tetap PT. Bank Central Asia, Tbk Kantor Cabang Pematangsiantar," SISTEMASI, vol. 7, no. September, pp. 250-258, 2018.

[18] V. M. M. Siregar, H. Sugara, and I. M. Siregar, "Perancangan Sistem Informasi Pendataan Barang Pada PT. Serdang Hulu,” J. Comput. Bisnis, vol. 12, no. 2, pp. 111-117, 2018.

[19] Y. I. Sri Rezeki Candra Nursari, "Perancangan Sistem Informasi Penjualan Online," J. TAM (Technology Accept. Model ), vol. 8, no. 2, pp. 107-116, 2017.

[20] V. M. M. Siregar, E. Damanik, M. R. Tampubolon, E. I. Malau, E. P. S. Parapat, and D. S. Hutagalung, "Sistem Informasi Administrasi Pinjaman (Kredit) Pada Credo Union Modifikasi (CUM) Berbasis Web," J. Tekinkom, vol. 3, no. 2, pp. 62-69, 2020.

[21] V. M. Siregar, H. Sugara, and G. A. Purba, "APLIKASI PENCATATAN LAPORAN PENJUALAN KITAKITA. NET BERBASIS WEB,” J. Tek. Inf. dan Komput., vol. 2, no. 1, pp. 80-86, 2019.

[22] V. M. Siregar and H. Sugara, "Perancangan Dan Implementasi Aplikasi Penggajian Berbasis Dekstop Pada Murni Sadar English Course," J. Tek. Inf. dan Komput., vol. 1, no. 2, pp. 42-48, 2018.

[23] V. M. M. Siregar, "Sistem Pendukung Keputusan Penentuan Insentif Bulanan Pegawai Dengan Menggunakan Metode Naïve Bayes," SISTEMASI, vol. 7, no. 2, pp. 87-94, 2018. 